\title{
A Study on Consumer Perception About Better-For-You Fruit Based Snacks in Kochi City
}

Prof. Daly Paulose Meppurath, Assistant Professor, St Teresas College, Ernakulam, PIN-682011,

M: 9895212897, daly.basil@gmail.com

Dr. Roshna Varghese, Assistant Professor, Rajagiri College of Social Science, Kakkanad, Kerala-682039

\begin{abstract}
It is a known fact that globally, increased awareness and health concerns are drawing people towards healthier snacking options. Through an empirical study, the researcher tries to ascertain whether the trend towards Better-For-You snacks is also prevalent in Kerala's most consumerist city - Kochi. The study discusses the perceptions of consumers in Ernakulam District about Better-For-You traditional fruit snacks available in the market. For this purpose a representative sample of 410 respondents residing in Ernakulam District were surveyed by way of convenience sampling across four different regions within the district. The results show that there is a widespread readiness among snack-lovers in the district to accept healthier options, albeit paying a premium price and absence of branded players in the traditional fruit snack segment. However, it can be seen that consumers surveyed are not willing to compromise on Taste or Freshness (represented by crispiness) appeal of such snacks under the pretext of health and attention to packaging is perceived to be a solution for this. The existence of a latent need for such products is very evident from the overwhelming endorsement for the category by the surveyed consumers.
\end{abstract}

Keywords: BFY, Snacks, Consumer, Perception, Health

\section{Introduction to study}

It is estimated that $20 \%$ of all meal occasions are snacks, and the snacking category includes sweet and salty foods, raw fruits and vegetables, dried fruits, nuts, seeds, chips, crackers and granola, chocolate and muesli bars. Snack foods can often be an impulse purchase, but they are also a convenient and portable alternative for busy people on the go, for those that exercise or enjoy the outdoors and for school lunch boxes (Cronin,2014).

Kerala's proposal to levy a $14.5 \%$ "fat tax" on the burgers, tacos, sandwiches, doughnuts and pizzas sold in fast-food restaurants in the state came as a surprise to most people. "This is more of a preventive measure as Kerala's food habits are changing dramatically. People are eating a lot of junk food and rejecting traditional food," Kerala's finance minister T.M. Thomas Issac told BBC in an interview (BBC, 2015). The Kerala Government's move highlights the growing concerns over detrimental health effects of unhealthy snacking.

\section{Snack foods market}

The Indian snack food market was estimated at \$3 billion (Rs13,950 crore) last year and nearly $85 \%$ of the salty snack market is comprised of potato chips. In this market, which is estimated at Rs.7,000 crore there are 5,000 players of which PepsiCo's and Haldiram Foods International Pvt. Ltd. are the market leaders in the branded segment. Brand Haldirams, is the largest brand by value in the Indian sweet and savouries market with an $18 \%$ share, according to Euromonitor International. According to data available with IMRB International, the western snacks market contracted by $1 \%$ in 2015 , while the traditional snack market expanded $4 \%$. This is an indication that more 
and more people are opting for the traditional way when it comes to choosing snacks (Vadakepat,2015).

\section{BFY Snack Foods: (Better-For-You Snack foods)}

The Better-For-You (BFY) snack category is gaining ground fast in an increasingly health-conscious world. Millennials have led the way in launching better-foryou snacks from a niche to mainstream market. This trend also percolates across generations with millennial moms buying more better-for-you snacks per month than any other generation. Some of the world's leading F\&B firms such as PepsiCo are now also catering to the wellness (snacks) category. These include Vegetable and fruit chips (including chips that are not made from either potatoes or corn, including apple chips, banana chips, jackfruit chips, sweet potato chips, carrot chips). Today, consumers are much more educated and interested in ingredients of packaged foods they consume and are looking for snacking options with clean labels, no artificial colors and flavors, no preservatives, GMOs, trans fat or high fructose corn syrup among ingredient list. This psychographic trend is driving growth in the BetterFor-You category. Buyers want to see organic, responsibly sourced, omega-3s, and environmentally friendly packaging promoted on a snack package in order to choose it over other packaged snacks. Additionally, certain nutrition labels have far more appeal to millennial consumers than other generations. Chief among them are dietary-related labels including gluten free, allergen free, and vegan (The Center for Generational Kinetics, 2017). According to the Organic Trade Association, organic snacking has grown by more than $15 \%$ per year since 2011 , well ahead of the global organic market at $11 \%$. According to the U.S. Snack World magazine, May 2013 , consumer demand for healthy snacks was the highest at $6.4 \%$ annual sales growth, ahead of value and indulgence, while overall snack food volume fell by $0.5 \%$. This highlights the current gaps and immense potential in the market for organic snacks (Dwyer,2003). However Euromonitor International indicates that, despite widespread and long-standing availability, reduced-fat sweet and savoury snacks account for just $5 \%$ of overall sweet and savoury snack value sales in North America in 2015 despite heavy investment and promotion. Clearly there are issues to be researched and addressed here (Mirosa and Lawson, 2011).

\section{Fruit Snack}

According to Euromonitor International, in the overall snack market, fruit snacks are among the bestperforming categories in sweet and savoury snacks. By the end of 2014, on a global level, fruit snacks were projected to have made value gains of just over $5 \%$, compared to regular chipsat $3 \%$ and $4 \%$ growth being recorded for tortilla/corn chips and extruded snacks (Velicova and Winkelhausen,2014).In Asia Pacific, fruit snacks are leading the pack with a $13 \%$ value increase in 2015, and in Latin America they top the growth charts with a deeply impressive $20 \%$. The Indian market boasts of traditional fruit snacks prepared from fruits like banana and jackfruit (Howell ,2003).

The banana belonging to family Musaceae is an important fruit of the world, especially of the tropics. Though India is the second largest producer of banana, India's share in the global processed market is less than $2 \%$, indicating its vast potential to emerge as a major exporter of banana (Obayopo and Taiwo, 2014). Additionally, post-harvest losses of banana are estimated to be more than $25 \%$ for India alone. Banana chips have been sold in all markets for a number of years and are imported in fairly large quantities.The Philippines is by far the most important supplier of banana chips, while dried bananas come mainly from Ecuador. Several other sources including Taiwan, India, Malaysia, South Africa, Venezuela and Colombia also sell dried bananas internationally(Kumar, K.P. \& Sagar,V.,2010).

\section{RESEARCH METHODOLOGY}

\section{Research Problem}

There is a huge opportunity for the organised sector in the production and marketing of banana and jackfruit chips. Kerala produces around 3 lakh tonnes of banana and 60 tonnes of banana chips annually. 
The market for banana and tapioca chips in Kerala is valued at Rs. 600 crore and Rs. 150 crore, respectively. As demand for these fruit based snacks keep growing outside Kerala and in West Asia, there is a decline in demand within the state and this calls for corrective steps including encouraging new players in the organised sector, enhancing research and development to innovate new products, creating brands and building a cost-effective model to increase distribution and reach. The hitherto cottage industry worth around Rs. 750 crore is in a changeover mode and is now getting a high-tech makeover (Joseph et al, 2010). Banana and jackfruit are becoming upscale as more branded snack food companies enter the market. Under threat from trendy brands like Groves, Lays and Bingo, the local industry is trying to make banana chips more appealing to the young generation. In an attempt to identify gaps in the consumer mindspace in the traditional snacks category, the researcher wishes to evaluate acceptance levels for an innovative product - de-oiled vacuum filled fruit snacks - among the target segment in Ernakulam District (Zhu et al, 2017).

\section{Significance of Study}

With consumers becoming increasingly wary of additives, allergens and chemicals in food and the effect on their health and that of their children, health food retailers are stocking more organic and whole food snacks.This study is of interest to retail giants which are concerned about farmer welfare, for wholesalers and retailers who have the potential to push indigenous products to the public, for consumer interest groups concerned about wellness of citizens and for policy makers who seek new initiatives that improve state of affairs through the State Horticulture Mission.

\section{Research Objectives}

The research question that this study seeks an answer to is: Is there a target market for de-oiled vacuum filled fruit chips in Ernakulam district? In line with this purpose, six specific research objectives are examined:
1) To understand snacking behavior of respondents from Ernakulam

2) To examine the factors influencing purchase of traditional snacks within Ernakulam

3) To understand extent of demographic influence on snacking behavior in Ernakulam

4) To understand extent of demographic influence on perception of de-oiled fruit chips

5) To evaluate customer perceptions about de-oiled vacuum filled fruit chips

6) To understand purchase intention within the market for de-oiled fruit chips

\section{Research Methodology}

In pursuance of the above objectives, the following methodology was adopted for conducting the study.

Population and Sample.

The population in this study entails the entire population of Ernakulam district which is 33 lakh.

Sample size estimation

According to the statistical formula applicable for sample size estimation for finite populations, the final sample size has been computed as shown below. For a normal distribution, the sample size, $\mathrm{n}$ is given by the formula

$n=\frac{N x}{\left((N-1) E^{2}+x\right)}$

where $\quad \mathrm{N}=$ population size

where $\quad x=Z\left(\frac{c}{100}\right)^{2} r(100-r)$

where $\quad r=$ response distribution

where $\mathrm{Z}\left(\frac{\mathrm{c}}{100}\right)=$ critical value for confidence level $\mathrm{c}$

Given that this researcher proposes to estimate sample size for a population size of $33,00,000$ individuals at $95 \%$ confidence level, with a $5 \%$ margin of error and expects a response distribution of $50 \%$, sample size is calculated as follows: 
$x=(1.96)^{2}(50)(100-50)=9604$

Therefore sample size, $n=\frac{3300000 \times 9604}{\left[(3300000-1) 5^{2}+9604\right]}=384$ In order to make conclusive inferences, the minimum sample size required is 384 . The research team has set the final sample size at 410 respondents.

Sampling procedure

Convenience sampling was adopted for sample selection. The respondents were chosen by way of convenience sampling at four Aditya Birla Group owned MORE supermarket outlets in different commercial belts of Ernakulam district.

Data Collection Procedure

Data collection was done by administration of personal intercept surveys using a structured questionnaire from a sample of 410 respondents within Ernakulam district.

\section{DATA ANALYSIS}

The demographic and behavioural profile of the survey respondents has been mapped in order to ascertain the sample characteristics and to demonstrate that the sample possesses the desired population traits. This is to make sure that the chosen sample characteristics can be safely extrapolated to the population.

\section{Profiling of Respondent}

The population in this study entails the entire population of Ernakulam district which is 33 lakh. In adopting sample size determination techniques for finite population, a sample size of 385 is required. However, the research team was able to collect responses from an effective sample of 410 individuals. The respondents were chosen by way of convenience sampling at four Aditya Birla Group owned MORE supermarket outlets in commercial belts of Ernakulam district.

\section{Personal Profile of Respondents}

The personal profile of the respondents is detailed in Table 1.1 and Table 1.2
Table 1.1:Personal Profile of Respondents

\begin{tabular}{|c|c|c|c|}
\hline Criteria & Category & $\begin{array}{l}\text { Number of } \\
\text { respondents }\end{array}$ & Percentage \\
\hline \multirow[t]{3}{*}{ Gender } & Male & 182 & 44.4 \\
\hline & Female & 228 & 55.6 \\
\hline & & 410 & $100 \%$ \\
\hline \multirow{3}{*}{$\begin{array}{l}\text { Marital } \\
\text { status }\end{array}$} & Married & 341 & 83.2 \\
\hline & Single & 69 & 16.8 \\
\hline & & 410 & $100 \%$ \\
\hline Household & Nuclear family & 378 & 92.2 \\
\hline \multirow[t]{2}{*}{ Type } & Joint/Extended & 32 & 7.8 \\
\hline & & 410 & $100 \%$ \\
\hline Household & 1 to 3 & 185 & 45.1 \\
\hline \multirow[t]{3}{*}{ Size } & 4 to 6 & 217 & 52.9 \\
\hline & 7 to 10 & 8 & 2 \\
\hline & & 410 & $100 \%$ \\
\hline \multirow{3}{*}{$\begin{array}{l}\text { Religion } \\
\text { practiced }\end{array}$} & Christian & 176 & 42.9 \\
\hline & Hindu & 182 & 44.4 \\
\hline & Muslim & 52 & 12.7 \\
\hline & & 410 & $100 \%$ \\
\hline
\end{tabular}

Table 1.2.: Age distribution of respondents(in years)

\begin{tabular}{|ll|}
\hline $\begin{array}{l}\text { Distribution Parameter: Age of respondent (in } \\
\text { years) }\end{array}$ \\
\hline Mean & 41.83 \\
Standard Deviation & 12.622 \\
Range & 61 \\
Minimum & 20 \\
Maximum & 81 \\
Skewness & 0.553 \\
\hline
\end{tabular}

Source: Primary data

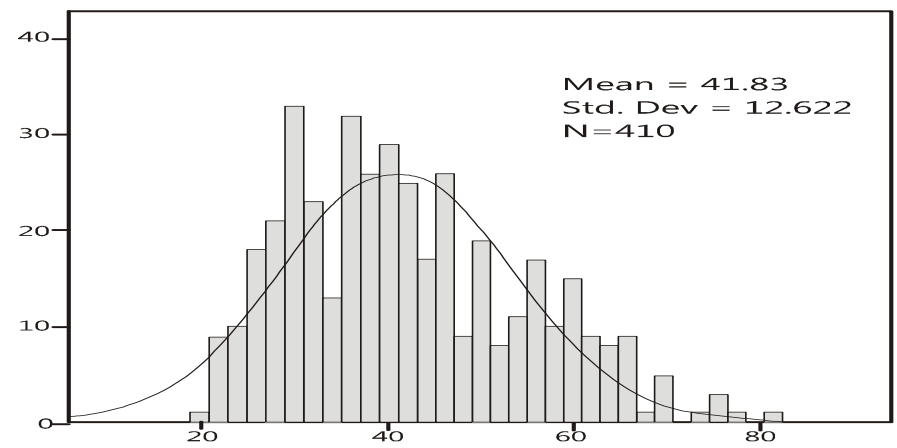

Age of respondent (in years) Figure 1.1: Histogram showing Age distribution of Respondents 
The distribution of the sample based on gender is even with around 44.4 percent of the respondents being male while 55.6 percent being female. The mean age of the sample is 41.83 years with the range and standard deviation being in line with the expected values of 61 and 12.622 respectively. The respondent age appears to follow a fairly normal distribution, as skewness of 0.553 is well within acceptable range as seen in Figure 1.1. This is a positive indicator of the randomness of the sample selection. Majority of the respondents are married (83.2\%) and belong to nuclear households (92.2\%) comprising upto 6 members in total. The highest proportion of respondents belong to Hindu community (44.4\%), followed closely by $42.9 \%$ from Christian denominations and $12.7 \%$ from Muslim faith.

Professional Profile of Respondents

Tables 1.3 describes the professional qualification of the respondents.

Table 1.3: Professional profile of Respondents

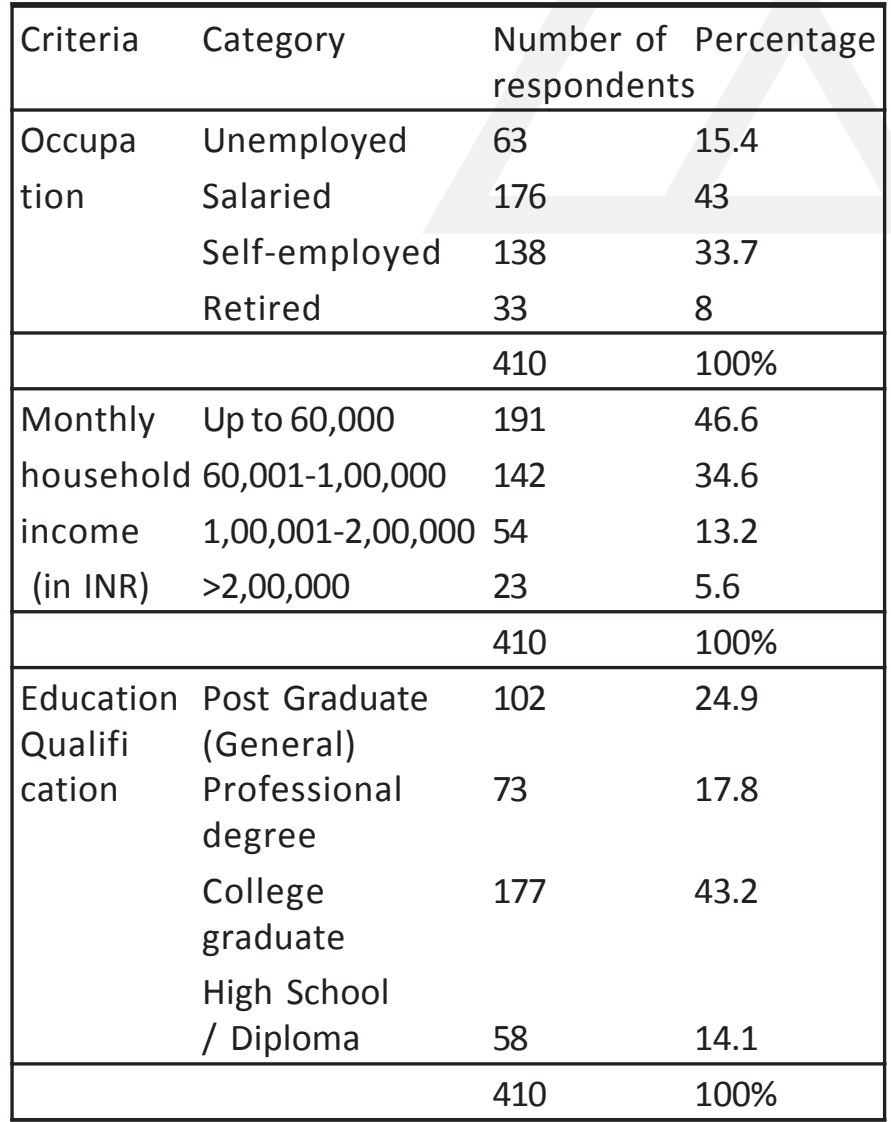

Source: Primary data
We can see that majority of the respondents are highly educated with $18 \%$ having professional qualifications like B-Tech, M-Tech, MBA, MD, CA etc. and $25 \%$ having regular post graduate degrees. Majority of the respondents belong to the Socioeconomic classification of Upper Middle Class going by the monthly household income with $53.4 \%$ belonging to Households earning in excess of Rs.60000 per month. Majority of the respondents $(43 \%)$ have a steady income source by way of salaries closely followed by $34 \%$ enterprising respondents belonging to the self-employed category. The professional description of the sample appears to match the desired profile of the premium customers who are likely to purchase a costlier variant of fruit chips for its health benefits.

\section{Behavioral Profile of Respondents}

This section tries to profile respondents based on their approach to snacking and general snacking behaviour. Profile details are listed below in Table 1.4 .

Table 1.4: Behavioral Profile of Respondents

\begin{tabular}{|c|c|c|c|}
\hline Criteria & Category & $\begin{array}{l}\text { Number of } \\
\text { respondent }\end{array}$ & Percentage \\
\hline $\begin{array}{l}\text { Frequency } \\
\text { of }\end{array}$ & $\begin{array}{l}\text { More than once } \\
\text { a week }\end{array}$ & 175 & 42.7 \\
\hline \multirow[t]{3}{*}{ snacking } & $\begin{array}{l}\text { Few times a } \\
\text { month }\end{array}$ & 148 & 36.1 \\
\hline & Occasion based & 87 & 21.2 \\
\hline & & 410 & $100 \%$ \\
\hline Deterrant & Health issues & 31 & 13.19 \\
\hline to & Health conscious & 118 & 50.21 \\
\hline \multirow[t]{3}{*}{ snacking } & Price of snacks & 28 & 11.92 \\
\hline & $\begin{array}{l}\text { Poor Quality of } \\
\text { Snacks }\end{array}$ & 58 & 24.68 \\
\hline & & 235 & $100 \%$ \\
\hline
\end{tabular}

Source: Primary data 
From Table 1.4, it can be deciphered that a large chunk of respondents $(78.8 \%)$ feast on local snacks regularly. Just $21.2 \%$ respondents use occasions only for having snacks. Of the 410 respondents, the individuals who do not have local snacks on a daily basis were asked about the factors which inhibit/deter them from having snacks daily. Of the 235 responses received, over $50 \%$ individuals attribute their reluctance to being health conscious. The next most popular response supported by $25 \%$ individuals was the poor quality of snacks in the market (particularly the reuse of oil in frying). Both these aspects point to a gap in the market for local snacks. These points are supportive of the market potential for a healthier snack option.

\section{Respondent estimate of Preferred Price for De- oiled Vaccuum filled Fruit chips}

An attempt was made to gain customer insights into the selling price for The Better-For-You snack options as this is a critical measure of market viability for any product. Table 1.5 summarises the findings from the survey.

Table 1.5 : Respondent estimate of Best Price for De-oiled fruit chips per 200 gm pack

\begin{tabular}{|ll|}
\hline $\begin{array}{l}\text { Distribution Parameter: Best price of de-oiled } \\
\text { fruit chips/200 gms }\end{array}$ \\
\hline Mean & Rs. 95.63 \\
Standard Deviation & Rs. 21.95 \\
Minimum price & Rs. 50 \\
Maximum price & Rs. 195 \\
Range & Rs. 145 \\
Skewness & 1.006 (Right skewed) \\
\hline
\end{tabular}

Source: Primary data

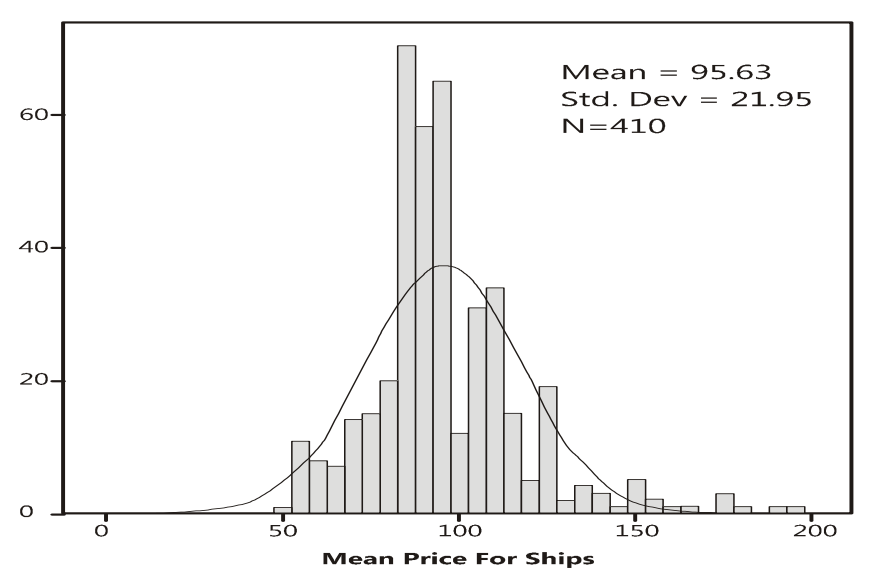

Figure 1.2:Histogram showing Preferred Price distribution of De-oiled fruit chips

From Table 1.5 and Fig 1.2, we can say that the most preferred price for the new product is Rs.96 per 200 gm pack as against a market price of Rs.75 for the regular chips. The product is likely to find a good market if it is priced at an average of Rs.96 with a standard deviation of + Rs.21. The price distribution is seen to be right skewed indicating that most of the respondents prefer prices less than or equal to Rs.96. Pricing above Rs.96 may not make much business sense in the market at the moment.

\section{Analysis of Ranked Data:}

Ordinal data in the questionnaire was analysed using Friedman Rank Test. This test is the non-parametric alternative to the one-way ANOVA with repeated measures. In other words, it is used to test for differences between groups when the dependent variable being measured is ordinal.

\section{Respondent Ranking of various attributes of Local} snacks according to preference

In order to get an idea about consumer preferences among various attributes of local snacks all 410 respondents were asked to rank their preferences in local snacks for various attributes across 7 categories. The mean ranks have been calculated using Friedman Test and the results have been tabulated and presented in Table 1.6. A lower mean rank is indicative of higher preference. 
Table 1.6: Friedman Rank Test for Respondent Ranking of various Attributes of Local Snacks

\begin{tabular}{|c|c|c|c|c|}
\hline Factor & $\begin{array}{l}\text { Mean } \\
\text { Rank }\end{array}$ & df & $\begin{array}{l}\text { Chi-Square } \\
\text { value }\end{array}$ & $\begin{array}{l}p- \\
\text { value }\end{array}$ \\
\hline Taste of Snack & 2.50 & & & \\
\hline Freshness of Snack & 2.78 & & & \\
\hline Ingredients in Snack & 3.76 & & & \\
\hline Price of Snack & 4.05 & & & \\
\hline $\begin{array}{l}\text { Health Aspect of } \\
\text { Snack }\end{array}$ & 2.79 & & & \\
\hline Availability of Snack & 5.80 & 6 & 1221.457 & .000 \\
\hline $\begin{array}{l}\text { Manufacturer/ } \\
\text { retailer brand name }\end{array}$ & 6.33 & & & \\
\hline
\end{tabular}

Source: Primary data

Here Friedmans Chi-square has a value of 1221.457 and a $p$ value of 0.000 and is statistically significant at $95 \%$ confidence level.?2 $(6, \mathrm{~N}=410)=1221.457$, $p<0.05$. Hence we reject the null hypothesis that the distribution in the ranks of attributes is the same and conclude that the distribution of the attribute scores is different. That is, there is a significant difference in the rankings of the various attributes. This means that for de-oiled chips to be preferred in the market, highest priority must be given to Taste which has the lowest mean rank followed by Freshness and Promise of Health to the consumer. Price and Brand name do not assume much importance for the consumer. The fact that availability is not ranked very high indicates that the consumer is willing to travel the whole distance to buy such a product as long as it rates high on taste, freshness and it is perceived to be a healthier alternative.

\section{Test of Association}

The Chi-square test of independence was undertaken to determine whether there is a significant association between chosen categorical parameters in the study.

Association between frequency of snack consumption and Age of respondent
The nature of association between frequency of consuming local snacks and Age of respondent is detailed in Table 1.7(a) and Fig. 1.3 and the extent of association in Table 1.7(b).

Table 1.7(a):Relationship between frequency of snack consumption and Age of respondent

\begin{tabular}{|c|c|c|c|c|c|c|}
\hline \multirow{2}{*}{$\begin{array}{l}\text { Frequency } \\
\text { of } \\
\text { snacking }\end{array}$} & \multicolumn{5}{|c|}{ Age of respondent } & \multirow{2}{*}{ Total } \\
\hline & & $\begin{array}{l}<35 \\
\text { years }\end{array}$ & $\begin{array}{l}36-45 \\
\text { years }\end{array}$ & $\begin{array}{l}46-60 \\
\text { years }\end{array}$ & $\begin{array}{l}>60 \\
\text { years }\end{array}$ & \\
\hline $\begin{array}{l}\text { More } \\
\text { than } \\
\text { once a } \\
\text { week }\end{array}$ & $\begin{array}{l}\text { Count } \\
\%\end{array}$ & $\begin{array}{l}46 \\
11.2 \%\end{array}$ & $\begin{array}{l}67 \\
16.3 \%\end{array}$ & $\begin{array}{l}32 \\
7.8 \%\end{array}$ & $\begin{array}{l}13 \\
3.2 \%\end{array}$ & $\begin{array}{l}158 \\
38.5 \%\end{array}$ \\
\hline $\begin{array}{l}\text { Few } \\
\text { times a } \\
\text { month }\end{array}$ & $\begin{array}{l}\text { Count } \\
\%\end{array}$ & $\begin{array}{l}24 \\
5.9 \%\end{array}$ & $\begin{array}{l}74 \\
18 \%\end{array}$ & $\begin{array}{l}37 \\
9 \%\end{array}$ & $\begin{array}{l}13 \\
3.2 \%\end{array}$ & $\begin{array}{l}148 \\
36.1 \%\end{array}$ \\
\hline $\begin{array}{l}\text { Occasion } \\
\text { based }\end{array}$ & $\begin{array}{l}\text { Count } \\
\%\end{array}$ & $\begin{array}{l}22 \\
5.4 \% \\
\end{array}$ & $\begin{array}{l}43 \\
10.5 \% \\
\end{array}$ & $\begin{array}{l}27 \\
6.6 \% \\
\end{array}$ & $\begin{array}{l}12 \\
2.9 \% \\
\end{array}$ & $\begin{array}{l}104 \\
25.4 \% \\
\end{array}$ \\
\hline Total & $\begin{array}{l}\text { Count } \\
\%\end{array}$ & $\begin{array}{l}92 \\
22.4 \%\end{array}$ & $\begin{array}{l}184 \\
44.9 \%\end{array}$ & $\begin{array}{l}96 \\
23.4 \%\end{array}$ & $\begin{array}{l}38 \\
9.3 \%\end{array}$ & $\begin{array}{l}410 \\
100 \%\end{array}$ \\
\hline
\end{tabular}

Table 1.7 (b):Chi-Square Tests of Independence

\begin{tabular}{|lll|}
\hline Method & $\chi^{2}$ Value & $p$ value \\
\hline Pearson Chi-Square & 9.059 & 0.170 \\
\hline
\end{tabular}

Source: Primary data

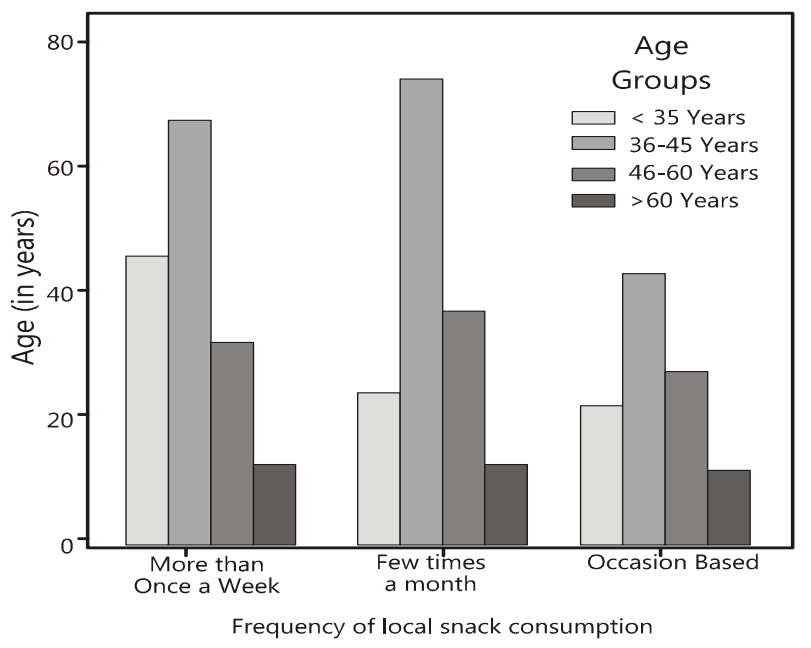

Figure 1.3: Histogram showing Frequency of Snacking and Age distribution of Respondents 
Table 1.7(a) and Fig 1.3 shows that consumption of local snacks is very prevalent among Kochiites with almost $75 \%$ of respondents reporting consumption several times a month. The most heavy consumers of local snacks are middle aged people (those aged between 36 to 45 years) with this category contributing most heavily in the terms of both weekly and monthly consumption ( $16 \%$ and $18 \%$ respectively). However, Chi-square test from Table 1.7(b) indicates that this association is not significant at the $5 \%$ level $(p>0.05)$. Hence it can be inferred that consumption of local snacks in Ernakulam district is rampant across all age groups irrespective of age.

\section{Association between frequency of local snack consumption and $\mathrm{HH}$ income of respondent}

The nature of association between snacking frequency and Household income of respondent is detailed in Table 1.8(a) and Fig.1.4. and the strength of association in Table 1.8(b).

Table 1.8(a): Relationship between frequency of snack consumption and $\mathrm{HH}$ Income

\begin{tabular}{|c|c|c|c|c|c|c|}
\hline \multirow{2}{*}{$\begin{array}{l}\text { Frequency } \\
\text { of } \\
\text { snacking }\end{array}$} & & \multicolumn{4}{|c|}{ Monthly HH Income (INR) } & \multirow{2}{*}{ Total } \\
\hline & & $\begin{array}{l}<I N R \\
60000 \\
100000\end{array}$ & $\begin{array}{l}\text { INR } \\
60001- \\
0\end{array}$ & $\begin{array}{l}\text { INR } \\
100001 \\
200000\end{array}$ & $\begin{array}{l}>\text { INR } \\
200000\end{array}$ & \\
\hline $\begin{array}{l}\text { More than } \\
\text { once a } \\
\text { week }\end{array}$ & $\begin{array}{l}\text { Count } \\
\%\end{array}$ & $\begin{array}{l}74 \\
18 \%\end{array}$ & $\begin{array}{l}52 \\
12.7 \%\end{array}$ & $\begin{array}{l}24 \\
5.9 \%\end{array}$ & $\begin{array}{l}8 \\
2 \%\end{array}$ & $\begin{array}{l}158 \\
38.5 \%\end{array}$ \\
\hline $\begin{array}{l}\text { Few times } \\
\text { a month }\end{array}$ & $\begin{array}{l}\text { Count } \\
\%\end{array}$ & $\begin{array}{l}67 \\
16.3 \% \\
\end{array}$ & $\begin{array}{l}54 \\
13.2 \%\end{array}$ & $\begin{array}{l}16 \\
3.9 \%\end{array}$ & $\begin{array}{l}11 \\
2.7 \%\end{array}$ & $\begin{array}{l}148 \\
36.1 \%\end{array}$ \\
\hline $\begin{array}{l}\text { Occasion } \\
\text { based }\end{array}$ & $\begin{array}{l}\text { Count } \\
\% \\
\end{array}$ & $\begin{array}{l}50 \\
12.2 \% \\
\end{array}$ & $\begin{array}{l}36 \\
8.8 \% \\
\end{array}$ & $\begin{array}{l}14 \\
3.4 \%\end{array}$ & $\begin{array}{l}4 \\
1 \% \\
\end{array}$ & $\begin{array}{l}104 \\
25.4 \% \\
\end{array}$ \\
\hline Total & $\begin{array}{l}\text { Count } \\
\%\end{array}$ & $\begin{array}{l}191 \\
46.6 \%\end{array}$ & $\begin{array}{l}142 \\
34.6 \%\end{array}$ & $\begin{array}{l}54 \\
13.2 \%\end{array}$ & $\begin{array}{l}23 \\
5.6 \%\end{array}$ & $\begin{array}{l}410 \\
100 \%\end{array}$ \\
\hline
\end{tabular}

Table 1.8 (b):Chi-Square Tests of Independence

\begin{tabular}{|llll|}
\hline Method & $\chi^{2}$ Value & $\phi$ & p value \\
\hline Pearson Chi-Square & 3.048 & \multicolumn{2}{c|}{0.000} \\
Phi coefficient $(\phi)$ & & 0.803 \\
\hline
\end{tabular}

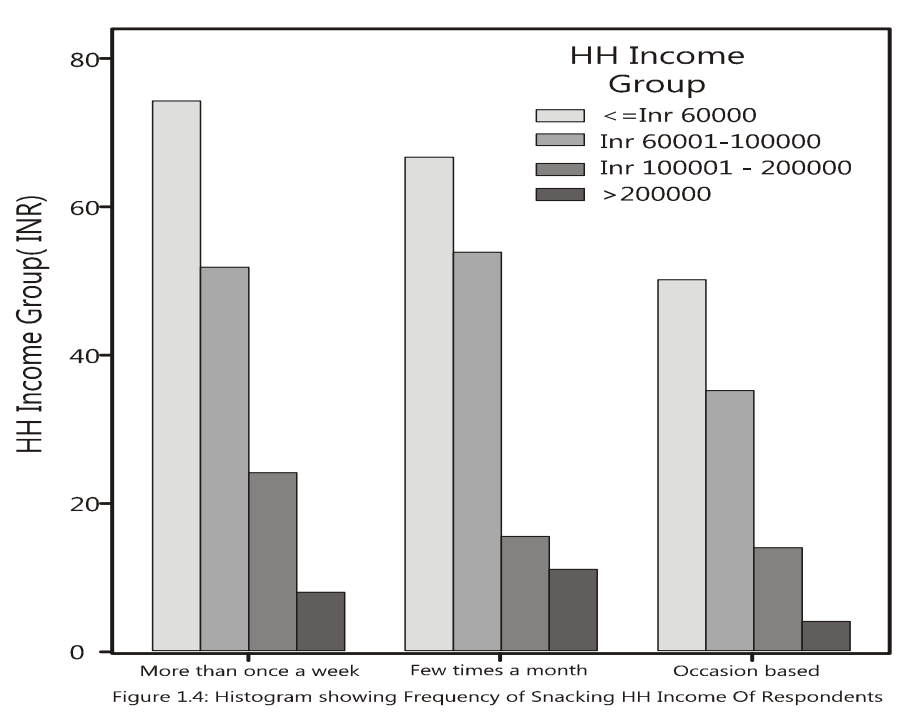

Table 1.8 (b):Chi-Square Tests of Independence

\begin{tabular}{|lll|}
\hline Method & $\chi^{2}$ Value & $p$ value \\
\hline Pearson Chi-Square & 12.048 & 0.000 \\
\hline
\end{tabular}

Source: Primary data

From Table 1.8(a) and Fig. 1.4 we can say that frequency of local snack consumption steadily declines with increase in $\mathrm{HH}$ income. This could be attributable to the preference for 'exotic' snacks by richer households due to which they could be shunning local/traditional snack varieties. From Table 1.8(b), it can be said that the relationship between frequency of local snack consumption and $\mathrm{HH}$ income is significant at $95 \%$ confidence level $(p<0.05)$. This supports the hypothesis that level of consumption of local snacks is closely connected to $\mathrm{HH}$ income.

\section{Association between frequency of snack consumption and Gender of respondent}

The nature of association between frequency of consuming local snacks and Gender of respondent is detailed in Table 1.9(a) and the extent of association in Table 1.9(b). 
Table 1.9(a):Relationship between frequency of snack consumption and Gender of respondent

\begin{tabular}{|c|c|c|c|c|}
\hline \multicolumn{2}{|c|}{ Frequency of snacking } & \multicolumn{2}{|c|}{ Gender } & \multirow[b]{2}{*}{ Total } \\
\hline & & Male & Female & \\
\hline $\begin{array}{l}\text { More than } \\
\text { once a week }\end{array}$ & $\begin{array}{l}\text { Count } \\
\%\end{array}$ & $\begin{array}{l}67 \\
16.3 \% \\
\end{array}$ & $\begin{array}{l}91 \\
22.2 \%\end{array}$ & $\begin{array}{l}158 \\
38.5 \% \\
\end{array}$ \\
\hline $\begin{array}{l}\text { Few times a } \\
\text { month }\end{array}$ & $\begin{array}{l}\text { Count } \\
\%\end{array}$ & $\begin{array}{l}66 \\
16.1 \% \\
\end{array}$ & $\begin{array}{l}82 \\
20 \% \\
\end{array}$ & $\begin{array}{l}148 \\
36.1 \% \\
\end{array}$ \\
\hline $\begin{array}{l}\text { Occasion } \\
\text { based }\end{array}$ & $\begin{array}{l}\text { Count } \\
\%\end{array}$ & $\begin{array}{l}49 \\
12 \% \\
\end{array}$ & $\begin{array}{l}55 \\
13.4 \% \\
\end{array}$ & $\begin{array}{l}104 \\
25.4 \% \\
\end{array}$ \\
\hline Total & $\begin{array}{l}\text { Count } \\
\%\end{array}$ & $\begin{array}{l}182 \\
44.4 \%\end{array}$ & $\begin{array}{l}228 \\
55.6 \%\end{array}$ & $\begin{array}{l}410 \\
100 \%\end{array}$ \\
\hline
\end{tabular}

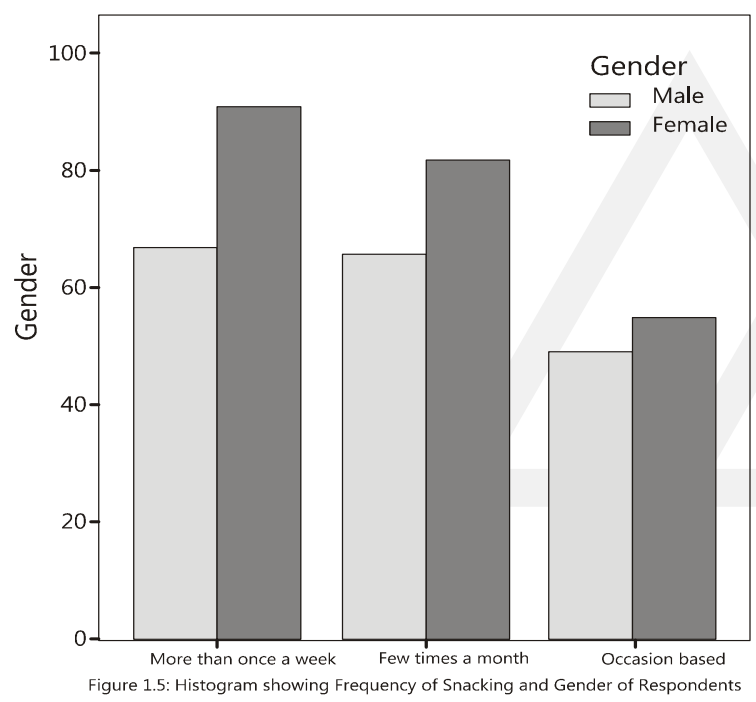

Table 1.9 (b):Chi-Square Tests of Independence

\begin{tabular}{|lll|}
\hline Method & $\chi^{2}$ Value & $p$ value \\
\hline Pearson Chi-Square & 0.568 & 0.753 \\
\hline
\end{tabular}

Source: Primary data

From Table 1.9(a) and Fig.1.5, we can see that frequency of traditional snack consumption is more among females than males. However, from Table 1.9(b), the relationship is not found to be significant at $95 \%$ level of confidence. Hence we can say that local snacks are consumed similarly across both gender groups. It is worth noticing that the difference in the consumption pattern between male and female groups closes in when it comes to occasion-based snacking (1.4\% difference).

\section{Association between frequency of snack consumption and religion of respondent}

The nature of association between snacking frequency and Religion of respondent is detailed in Table 1.10(a) and Fig.1.6. and the extent of association in Table 1.10(b).

Table 1.10(a):Relationship between frequency of snack consumption and Religion of respondent

\begin{tabular}{|llllll|}
\hline \multirow{2}{*}{ Frequency of snacking } & \multicolumn{5}{c|}{ Religion } \\
\cline { 3 - 6 } & & \multicolumn{3}{c}{ Total } \\
\cline { 3 - 6 } & & \multicolumn{3}{c}{ Christian Hindu } & Muslim \\
\hline More than & Count & 60 & 78 & 20 & 158 \\
once a week & $\%$ & $14.6 \%$ & $19 \%$ & $4.9 \%$ & $38.5 \%$ \\
\hline Few times & Count & 63 & 71 & 14 & 148 \\
a month & $\%$ & $15.4 \%$ & $17.3 \%$ & $3.4 \%$ & $36.1 \%$ \\
\hline Occasion & Count & 53 & 33 & 18 & 104 \\
based & $\%$ & $12.9 \%$ & $8 \%$ & $4.4 \%$ & $25.4 \%$ \\
\hline Total & Count & 176 & 182 & 52 & 410 \\
& $\%$ & $42.9 \%$ & $44.4 \%$ & $12.7 \%$ & $100 \%$ \\
\hline \hline
\end{tabular}

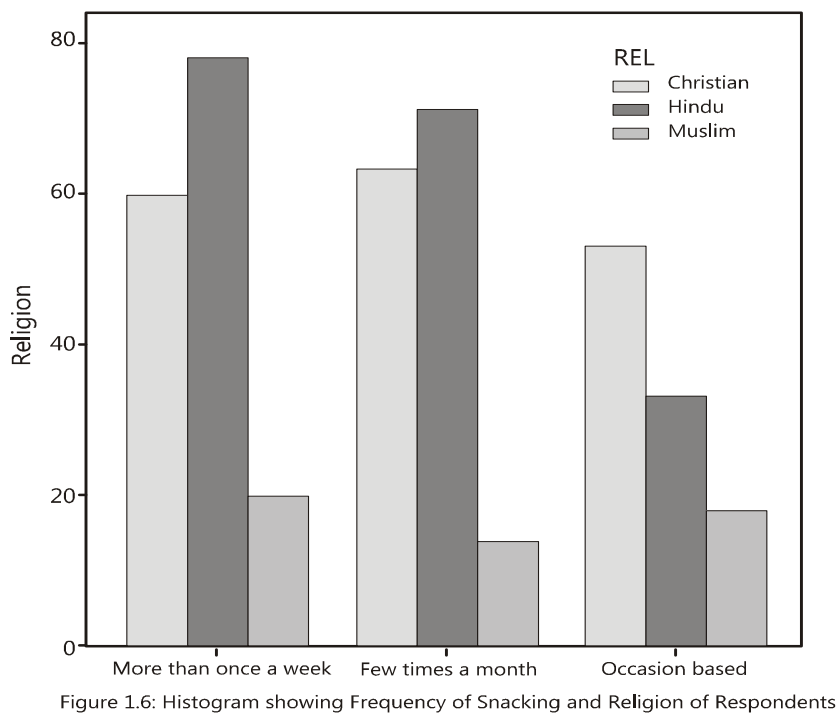


Table 1.10 (b):Chi-Square Tests of Independence

\begin{tabular}{|lll|}
\hline Method & $\chi^{2}$ Value & p value \\
\hline Pearson Chi-Square & 10.502 & 0.033 \\
\hline
\end{tabular}

Source: Primary data

From Table 1.10(a) and Fig 1.6, we can say that frequency of consuming local snacks is highest among Hindus compared to Muslims and Christians. Christians take the lead when it comes to Occasionbased snacking with $13 \%$ of the $25 \%$ respondents who restrict local snack consumption to special occasions being Christians. Table 1.10(b) establishes the significance of the relationship between frequency of snacking and religion with a $p$ value $<0.05$. Hence we can confidently say that religion is significantly associated with snacking habits.

\section{Tests of Difference:}

In this section, it was tested to find if there is a variation in perception of de-oiled vacuum filled fruitbased chips across different demographic groups (namely gender, age, marital status, $\mathrm{HH}$ income, religion, education, occupation). The difference in perception of the de-oiled chips with respect to Gender and Marital status is tested using independent samples t-test and One-way ANOVA is used to test for significant differences due to all other demographic influences.

\section{Independent samples t-test}

The independent-samples t-test compares the means between two unrelated groups on the same continuous, dependent variable. Here, independent samples t-test is performed to test if there is a significant difference in overall perception about deoiled chips based on gender and marital status and the results are presented in Table 1.11.
Table 1.11:Variation in respondent perception about de-oiled chips based on gender, marital status

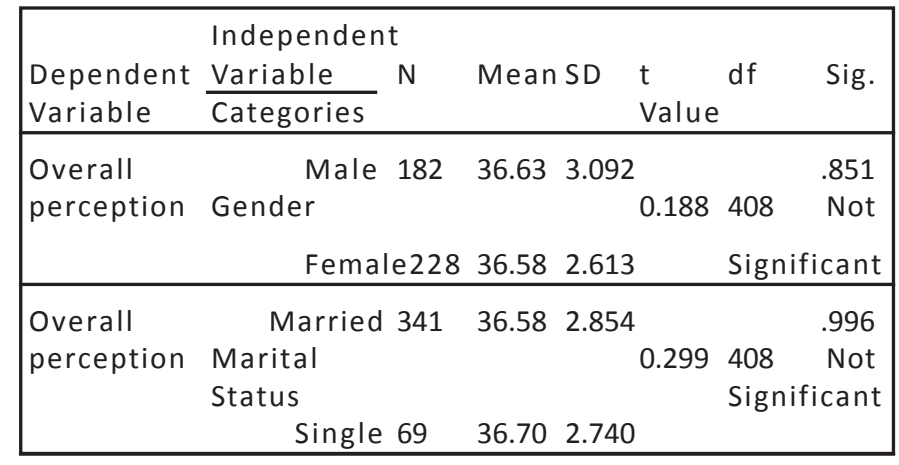

Source: Primary data

An independent samples t-test revealed that the group means were not significantly different for both demographic factors namely gender and marital status. The difference in means of both groups were very minimal $(0.05$ for Gender in favour of Males and 0.12 for Marital status with single respondents leading the way).

\section{One-way ANOVA}

Analysis of Variance (ANOVA) is performed to test whether the difference in means from more than two groups is statistically significant. Here, one-way ANOVA is performed to test if there is a difference in overall customer perception about de-oiled chips based on age, monthly household income, religion and occupation of the respondent. The results are shown in Table 1.12. 
Table 1.12.:Variation inPerception across age, household income, religion, occupation

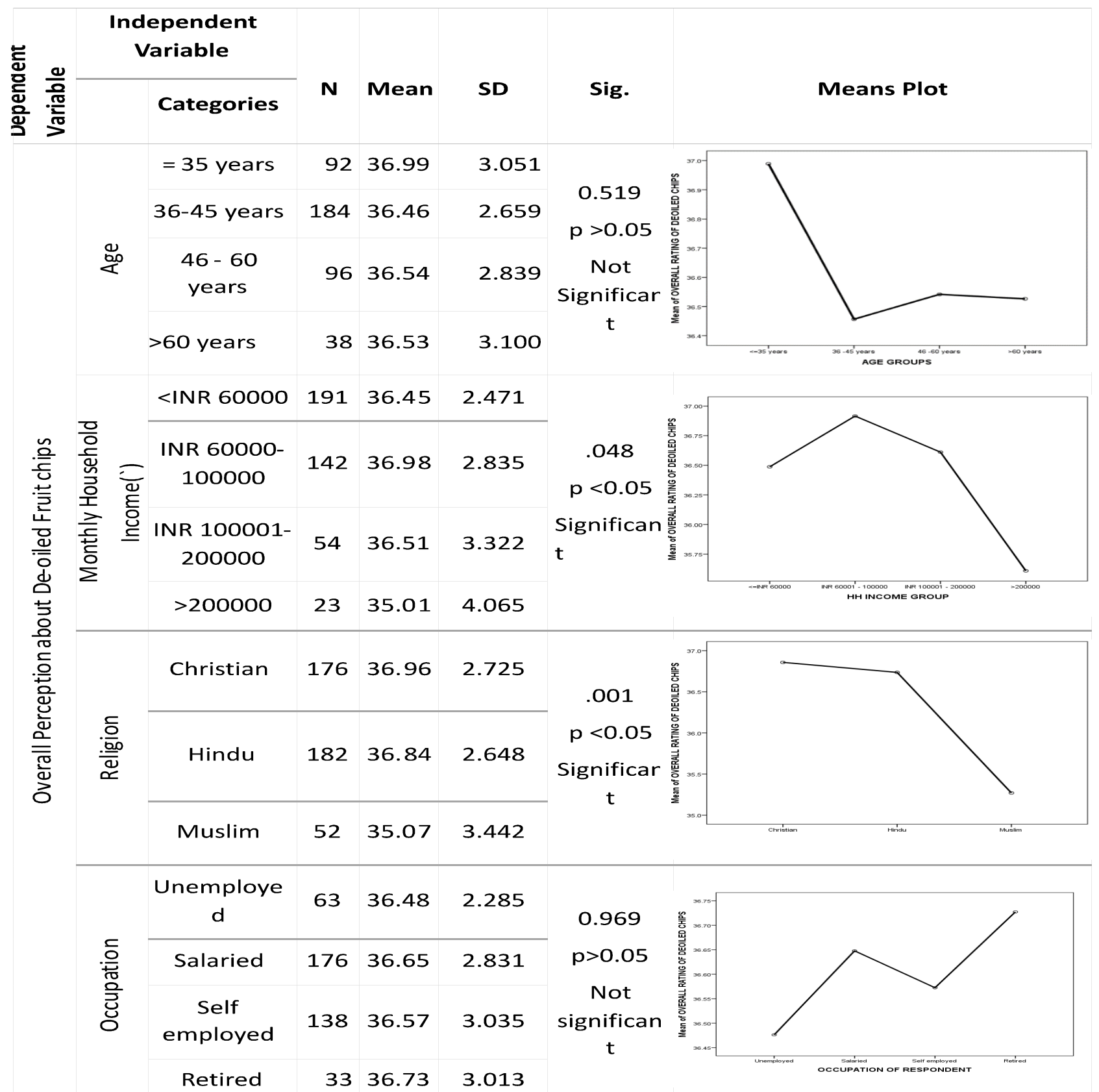

From the Table 1.12, it can be seen that there is a statistically significant effect of monthly household income with rich households earning over INR $200000(M=35.01, S D=4.065)$ rating the product lower than 
other income groups. Specific feedback was taken from these groups to identify reasons for the same and the responses have been enumerated in the Suggestions and Recommendations sections. There is also a statistically significant effect of religion, with Muslims ( $M=35.07, S D=3.442$ ) rating the de-oiled chip samples lower than Christians $(M=36.96$, $S D=2.725)$ and Hindus $(M=36.84, S D=2.648)$. This means that firms marketing such products can ignore these segments (Muslims and very rich households) in their initial marketing efforts. Hence it can be concluded that at least one of the group means is significantly different from the others in each of the two cases. It is possible to conduct a post hoc followup test to determine which means differ significantly from each other but that is beyond the scope of this study and hence omitted.The interaction between perception and variables ageand occupation is not significant.

Test of Comparison and Correlation:

Relative correlation

Correlation analysis was performed to examine the contribution of various product attributes to overall consumer perception scores for de-oiled fruit chips and the results are listed in Table 1.13.
Table 1.13: Relative correlation of product attributes with Overall perception score of product

$\begin{array}{ll}\text { Attribute considered } & \begin{array}{l}\text { Perception Score } \\ \text { Appearance }\end{array} \\ \text { Crispiness } & 0.741^{*} \\ \text { Sweetness } & 0.620^{*} \\ \text { Freshness } & 0.644^{*} \\ \text { Taste/Flavor } & 0.828^{*} \\ \text { Size/Dimensions } & 0.423^{*} \\ \text { Aroma } & 0.670^{*} \\ \text { Color } & 0.487^{*} \\ \text { Brand name } & 0.454^{*} \quad \\ \text { Source: Primary data } & \end{array}$

The data in Table 1.13 reveals that every factor/ attribute considered is significantly correlated with the overall scores of perception about de-oiled chips. The highestcorrelation is between taste $(r=0.828$, $p<0.05)$ and perception followed by crispiness ( $r=$ $0.771, p<0.05$ ). The correlation figures are moderate when it comes to size, colour and brand name.

Dichotomous comparison

An attempt has been made to compare customer expectations from fruit chips on various parameters and Performance of De-oiled chip options in the market on these specified parameters. The objective is to identify the specific attributes that fall below and those that fall above customer expectation levels from the product category 'fruit chips'. These results in Table 1.14 will give marketers an idea about areas where improvement is required.

Table 1.14: Comparison of Customer expectation from category \& Actual Product performance CUSTOMER EXPECTATION FROM CATEGORY ACTUAL PRODUCT PERFORMANCE

\begin{tabular}{|c|c|c|c|c|c|c|c|c|c|}
\hline & Mean & Range & SD & Skew & & Mean & Range & SD & Skew \\
\hline Appearance & 3.94 & 4 & 0.750 & -1.093 & Appearance & 4.07 & 4 & 0.517 & -1.615 \\
\hline Crispiness & 4.27 & 4 & 0.586 & -1.013 & Crispiness & 4.18 & 3 & 0.472 & -0.177 \\
\hline Sweetness & 3.76 & 6 & 1.112 & -1.030 & Sweetness & 4.29 & 4 & 0.652 & -1.485 \\
\hline Freshness & 4.53 & 4 & 0.630 & -1.715 & Freshness & 4.23 & 4 & 0.557 & -1.085 \\
\hline Taste & 4.50 & 4 & 0.619 & -1.641 & Taste & 4.17 & 3 & 0.588 & -1.068 \\
\hline Size & 3.60 & 4 & 1.073 & -1.115 & Size & 3.97 & 4 & 0.636 & -1.218 \\
\hline Aroma & 3.64 & 4 & 0.949 & -1.446 & Aroma & 3.44 & 4 & 1.076 & -1.074 \\
\hline Colour & 3.64 & 4 & 0.944 & -1.193 & Colour & 3.90 & 4 & 0.688 & -1.245 \\
\hline Brand & 4.78 & 3 & 0.510 & -1.264 & Brand & 4.36 & 4 & 0.603 & -1.102 \\
\hline Overall rating & 36.65 & 21 & 3.863 & -0.724 & Overall Rating & 36.60 & 18 & 2.832 & -0.507 \\
\hline
\end{tabular}

Source: Primary data 
From Table 1.14,we can see that the de-oiled fruit chips falls short on customer expectations in the areas of Crispiness, Freshness feel, Taste, Aroma and Brand name. The product falls slightly below expectations at an overall level also but that difference is negligible.

However, when considering the skewness values of various attributes under perception of de-oiled fruit chips, it can be seen that the distribution is entirely negatively skewed which is a positive indication that majority of the responses fall on the higher end of the scale. This means that in absolute terms, respondents tend to rate the performance of de-oiled chips highly. It is when comparing with certain expected levels of crispiness, freshness, taste and aroma that the brand falls slightly behind.

\section{Predictive analysis using linear regression:}

It is imperative to understand the factors which can predict consumer buying behavior. The studyattempted to explore the extent of influence of multiple predictor variables (namely Age of respondent, Price of chips and Overall rating of deoiled fruit chip options) on consumer purchase decision of the product.Multiple regression was performed to investigate the role of factors like Price, Overall rating of de-oiled chips and Age of respondent in influencing final purchase decision of the product. Preliminary analyses was conducted to ensure no violations of normality, linearity and multicollinearity among the factors. All VIF values were less than 10 and standardized residual values were within acceptable range.

Table 1.15: Multiple regression table

\begin{tabular}{|c|c|c|c|c|c|}
\hline & $\mathrm{R}$ & $\mathrm{R} 2$ & B & B & $\begin{array}{l}\text { Sig. } \\
\text { level }\end{array}$ \\
\hline Model & 0.474 & 0.225 & & & \\
\hline $\begin{array}{l}\text { Price of } \\
\text { chips }\end{array}$ & & & 0.13 & 0.004 & 0.003 \\
\hline $\begin{array}{l}\text { Perception of } \\
\text { chips }\end{array}$ & & & 0.43 & 0.108 & 0.000 \\
\hline Age of buyer & & & -0.124 & -0.007 & 0.004 \\
\hline
\end{tabular}

Source: Primary data
From Table 1.15, we can see that the three variables together measured $23 \%$ of the variance in buying decision. In the final model, all three predictor variables were statistically significant with consumer perception of de-oiled chips recording higher $\beta$ value $(\beta=0.430)$ than price of de-oiled chips $(\beta=0.133)$. This means that people will buy de-oiled fruit-based chips if the overall perception is good, and the influence of price factor is only secondary. The role of age of respondent in purchase decision was also significant but the relationship was found to be negative ( $\beta=$ 0.124).This means that higher the age, lesser is the likelihood of buying de-oiled chips at the given best price of Rs.95.6 per 200 gm packet. Hence we can say that purchase decision of de-oiled chips is influenced strongly by perception and moderately influenced by Price of the product and age of the buyer.

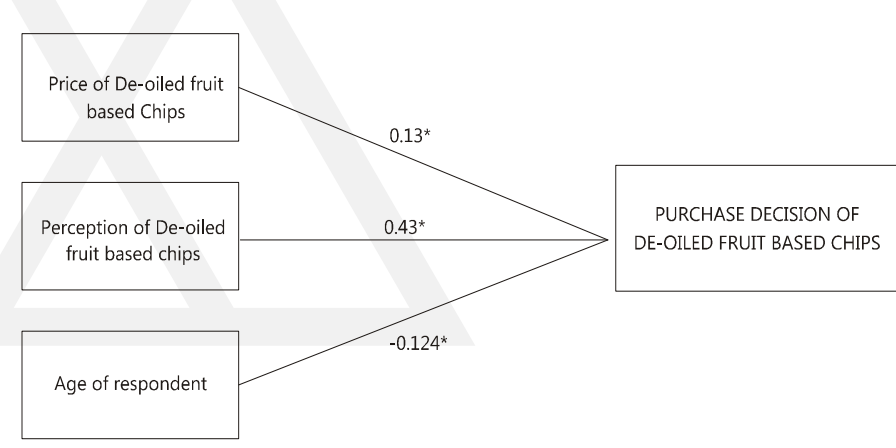

Figure 1.7: Factor Structure for Purchase decision of De-oiled Fruit chips

Fig 1.7 presents the path analysis for purchase decision of De-oiled Fruit chips in the present scenario. It can be said that $13 \%$ of the respondent purchase decision is influenced by Price, $43 \%$ by consumer perception of the product and $12 \%$ is explained by the factor Age of buyer. It is worth noting that purchase decision is negatively correlated with age. This means that the lower the age of the buyer, the higher is the possibility to buy the product. Another interesting point is that price is no match for promise of good health. All these relationships are significant at the $95 \%$ confidence level. 


\section{Percentage Analysis:}

\section{Respondent Purchase Intention for De-Oiled Fruit Chips}

Table 1.16: Likelihood for Respondent Purchase and Recommendation of the Product

\begin{tabular}{|llrr|}
\hline Criteria & $\begin{array}{l}\text { Category } \\
\text { respondents }\end{array}$ & \multicolumn{2}{c|}{ Number ofPercentage } \\
\hline \multirow{4}{*}{ Buy } & Will not buy & 21 & 5.1 \\
& Will buy & 246 & 60.0 \\
& Will buy for sure & 143 & 34.9 \\
\hline & 410 & $100 \%$ \\
\hline \multirow{4}{*}{ Recommend } & Will not recommend & 27 & 6.6 \\
& Will recommend & 241 & 58.8 \\
& sure & 142 & 34.6 \\
\hline & & \\
\hline
\end{tabular}

Source: Primary data

In concluding the analysis, it is worth noting in Table 1.16 that over 94 percent respondents expressed willingness to buy de-oiled chips and 93\% said they will recommend such a healthy option to their family and friends.

\section{FINDINGS AND SUGGESTIONS}

\section{Representativeness of Sample}

From Table 1.2 and Fig.1.1, it can be inferred that the sample is representative of the population. The mean age of the sample follows a normal distribution with skewness being within acceptable range, an indicator of the randomness in the sampling process. From Table 1.1, it can be seen that gender-wise distribution of the sample is also fairly even with $44 \%$ and $56 \%$ representation of males and females.

Further insights can be obtained about the representativeness of the sample from Table 1.3. The fact that more than half the respondents belong to upper middle income households earning in excess of Rs.60000 per month and more than $85 \%$ respondents have college degrees shows that the chosen respondents may be suitable target market for premium products marketed on a health platform.
Over $75 \%$ respondents are part of the working population and can be viewed as having purchasing power by themselves.

As far as snacking behavior is concerned, almost $80 \%$ respondents are avid consumers of traditional snacks not limiting themselves to special occasions (See Table 1.4). Of the people who indulge in limited snacking, over $50 \%$ have attributed it to being health conscious by nature and $25 \%$ have concerns about the quality of local snacks available. Both these aspects present a huge business opportunity for marketers to enter the market offering a healthier alternative in the traditional snacking segment.

\section{Consumer Preference among various Attributes in Traditional Snacks}

In Table 1.6, majority of respondents have ranked taste as the most important attribute in purchase of local snacks. The second highest priority is given to freshness feel (described as bite, smell or crispiness) of local snacks and coming in at third place is the health aspect of snacks. The fact that there is a significant difference in the rankings of the various attributes ( $p$ value $<0.05$ ) shows that the respondents rate each of the attributes differently. Price and Brand name do not assume much importance for the consumer. The fact that availability is not ranked very high indicates that the consumer is willing to travel the whole distance to buy the product as long as it rates high on taste, freshness and it is perceived to be a healthier alternative. It maybe recommended that innovative marketers can price the product at a premium and still find buyers if the other three aspects of taste, freshness and health is guaranteed.

\section{Demographic influences on Respondents Consumption of Local snacks}

Table 1.7(a) and Fig $\mathbf{1 . 3}$ shows that consumption of local snacks is very prevalent among Kochiites with almost $75 \%$ of respondents reporting consumption several times a month. Hence it can be inferred that consumption of local snacks in Ernakulam district is rampant across all age groups. The most heavy consumers of local snacks are middle aged people 
(those aged between 36 to 45 years) with this category contributing most heavily in the terms of both weekly and monthly consumption (16\% and $18 \%$ ) but the Chi-square test results indicate that this inference maybe just by chance and needs to be probed further.

From Table 1.8(a) and Fig. 1.4 we can say that frequency of local snack consumption steadily declines with increase in $\mathrm{HH}$ income. This could be attributable to the preference for 'exotic' snacks by richer households due to which they could be shunning local/traditional snack varieties. The significance of the Chi-square test in Table 1.8(b) supports the hypothesis that level of consumption of local snacks is closely connected to $\mathrm{HH}$ income. Marketers need to try and change perceptions about local snacks among the rich households if it has to penetrate this lucrative segment. This perceptual change can be achieved by using the health platform to differentiate the product to override this 'local' tag. As far as gender influence is concerned, local snacks are consumed similarly across both gender groups [Table 1.9(a) and (b).]

From Table 1.10(a) and Fig 1.6, we can say religion is significantly associated with consumption of local snacks. Frequency of consuming local snacks is highest among Hindus compared to Muslims and Christians. Christians take the lead when it comes to occasion-based snacking with $13 \%$ of the $25 \%$ respondents who restrict local snack consumption to special occasions being Christians.

To summarise, it may be inferred that marketers of BFY snacks needs to initially focus on middle class households while working on changing the 'uncool' perception of 'traditional' snacks among the rich. Consumers belonging to Hindu faith are soft targets for 'traditional snacks' and festival seasons appear to be a good time to target Christian communities.

\section{Relevance of Chosen Attributes for Generating Overall Perception Scale for De-oiled Fruit Chips}

From Table 1.13. we can see that the 9 attributes chosen by the research team for assessing Consumer
Perception about the test-marketed product are all strongly correlated to the construct being studied. Of all attributes, taste, crispiness and appearance are strongly correlated to overall perception scores of deoiled Fruit chips. Reiterating the earlier observation, marketers in this business need to focus on Taste, crispiness and appearance to strike a chord with the consumers. It maybe useful to note that Brand name is only moderate correlated with perception scores. This goes to say that, at the end of the day, it is not brand name that drives this product category, but the taste and quality that can be guaranteed to the consumer.

\section{Respondent Estimate of Price of Test Marketed Product and its Relevance}

From Table 1.5 and Fig.1.2, it is clear that the most preferred price for the new product is Rs.96 per 200 gm pack as against a market price of Rs. 75 per 200 gm for the regular fruit chip variants of banana and jackfruit. The price distribution is seen to be right skewed indicating that most of the respondents prefer prices less than or equal to Rs.96. This could indicate that penetration pricing maybe opted at introduction stage of the Product Life Cycle and pricing above Rs.96 may not make much business sense for the time being. Once a brand equity has been established, it could make sense to price higher targeting the discerning consumer.

\section{Demographic Influence on Overall Perception of De-Oiled Fruit Chips}

From Table 1.11 and Table 1.12, it can be inferred that respondent perception about de-oiled fruit chips does not vary based on gender, marital status, age or occupation. The product appears to have the same appeal across all these demographic groups. However, there seems to be a statistically significant effect of monthly household income with rich households earning over INR 200000 rating the product lower than other income groups. There is also a statistically significant effect of religion, with Muslims rating deoiled chips lower than their counterparts from other religious denominations. This means that marketers 
can ignore these segments (Muslims and very rich households) in their initial marketing efforts and undertake specific research to identify and address their concerns about the product.

\section{Comparison of Respondent Expectations from Fruit Chip Variants and Performance of such Products in the Market}

In Table 1.14, the researchers have compared customer expectations from Fruit-based chips on various parameters against Performance of De-oiled fruit chips on these specified parameters. This gives an idea to the company about the product parameters which need to be improvised upon. Here, we can see that the current brands fall short on performance expectations in the areas of Crispiness, Freshness feel, Taste, Aroma and Brand name. However, the good news is that at an overall perspective, even though the product falls slightly below expectations, that difference is negligible. This means, with some focus on fail points, such a healthier, innovative product can certainly be a hit among consumers in Ernakulam. The other good news from the skewness estimates of Table $\mathbf{1 . 1 4}$ is that in absolute terms, respondents tend to rate the performance of de-oiled fruit chips highly. It is when comparing with traditional fruit chips that the healthier variants fall slightly behind.

The overwhelmingly common comments pertaining to taste are that the de-oiled variants leave a raw taste behind and sticks to the teeth when chewing. As a result, crispiness and freshness are compromised. The other observation regarding taste is excessive sweetness which may be balanced with a pinch of salt. Comments pertaining to colour and chip dimensions were all positive. The aroma of traditional chips was observed to be missing but most consumers looked at that in a positive light as it validated the absence/near absence of oil.

\section{Factors Influencing Consumer Purchase Decision of De-oiled Fruit Chips}

The extent of influence of multiple predictor variables (namely Age of respondent, Price of chips and Overall rating of de-oiled chips) on consumer purchase decision of the product is studied in Table 1.15. Multiple regression was performed to investigate the role of various factors like Price, Overall rating of deoiled fruit chips and Age of respondent in influencing final purchase decision of the product.

Fig.1.7 show that $13 \%$ of the respondent purchase decision is influenced by price, $43 \%$ by consumer perception of the product and $12 \%$ is explained by the factor Age of buyer. This means that people will buy de-oiled chips if the overall perception is good, and the influence of price factor is only secondary. It is worth noting that purchase decision is negatively correlated with age. This means that the lower the age of the buyer, the higher is the possibility to buy the product and vice versa. It maybe helpful for decision makers to note that price is no match for promise of good health.

\section{General Outcome of the Perception Survey}

The concluding remarks of the perception survey are endearing as can be seen in Table 1.16. At the end of the study, over 94 percent respondents surveyed expressed willingness to buy de-oiled fruit chips and 93\% said they will recommend a healthier product such as this to their family and friends. This is a positive stroke for marketers planning for such innovative product launches. A little more focus on areas of improvement in the current products can surely garner such BFY brand of fruit snacks good market acceptance.

\section{References:}

1. Cronin,J., McCarthy,M. \& Brennan,M. (2014). The bigger society: considering lived consumption experiences in managing social change around obesity. European Journal of Marketing, 48(9):1558-1578

2. Dwyer,S. (1992). Healthy' or Traditional, Snacks Maintain Their Customer Appeal

NPN, National Petroleum News. 84( 8), 38

3. Howell, D. (2003). Organic and regional tastes drive salty snacks. DSN Retailing Today.42( 10),22. 
4. Joseph,A., Poojara,R \& Kowsalya,S (2010).Prevalence and epidemiological factors associated with obesity among adults in Ernakulam district, Kerala. Indian Journal of Nutrition and Dietetics (2008).45(10): 399-409

5. Kumar, K.P. \& Sagar,V.(2010). Recent advances in drying and dehydration of fruits and vegetables: a review. 47(1):15-26

6. Mirosa, M. \& Lawson,R. (2011). Revealing the lifestyles of local food consumers. British Food Journal. 114(6):816-825

7. Obayopo,S. \& Taiwo,K. (2014).Development of a plantain slicing device. Journal of Food Science Technology. 51(7):1310-1317
8. The Center for Generational Kinetics (2017). Report on Better-For-You Snacks: The New Snacking Reality

9. Vadakepat, V.M. (2015). Diaspora affluence in rural markets: consumers' shift from traditional to global products. International Journal of Commerce and Management.25(4): 641-653

10. Velicova,E. \& Winkelhausen,E. (2014).Physical and sensory properties of ready to eat apple chips produced by Osmo-convective drying. Journal of Food Science Technology. 51(12):3691-3701

11. Zhu,Y., Zhang,M. \& Wang,Y.G.(2015). Vacuum frying of peas: effect of coating and pre-drying. Journal of Food Science Technology. 52(5):31053110 